\title{
The Current Forest Status and Plant Species Diversity in Sekelemariam State Forest, Ethiopia
}

\author{
Yitayal Tebeje \\ A Department of Natural Resource Management, Debre Markos University, Debre Markos,269, Ethiopia
}

\begin{abstract}
The aim of this study was to explore the characteristic of structure; species composition and species diversity in Sekelemariam State forest to enhance the forest's plant biodiversity conservation and management practices through minimize the illegal deforestation practices by the local communities. The floristic composition and relative dominance of trees were studied in $66(10 \mathrm{~m} \times 20 \mathrm{~m})$ sample plots. A systematic sampling of plot of (10 $\mathrm{m} \times 20 \mathrm{~m})$ in each site was done to take vegetation samples. The data of tree individuals have served to give insight into the stand density, basal area, and frequency number of DBH class ranges. There were a large number of DBH class ranges but there were low DBH values. The species composition of Sekelemariam State forest is low rich and diversity with moderate density. The dominant species of trees were Croton macrostachys, Cupressus lusitanica Mil and Albizzia schimperiana, respectively. The maximum and minimum IVI values of trees were 34.97 and 0.66 of Croton macrostachys and Terminalia schimperiana, respectively. The density of vegetation in study area increases with increasing of DBH and height classes; this implies that the predominance of plantation tree individuals as the local community had been logging large sized natural tree species. The DBH size class distribution of trees in Sekelemariam State forest is shown to be on L-shape curve, which is high abundance of small trees.
\end{abstract}

Keywords: Species diversity, Species richness, DBH, Diversity Indices.

DOI: $10.7176 / \mathrm{JBAH} / 9-24-02$

Publication date: December $31^{\text {st }} 2019$

\section{Introduction}

At the beginning of the twentieth century around 420,000 square kilometers (35\% of Ethiopia's land) was covered by trees but recent research indicates that forest cover is now less than $14.2 \%$ due to population growth (Mesfin Sahle. 2011). Ethiopia is characterized by having nine vegetation types distinguished throughout the country: Afroalpine and Sub- Afro alpine, Dry Evergreen Montane Forest, Moist Evergreen Montane Forest, AcaciaCommiphora (Small Leaved) Woodland, Combretum-Terminalia (Broad Leaved) Woodland, Lowland Dry Forests, Wetland (swamps, lakes, rivers and riparian) Vegetation, Evergreen Scrub Vegetation, and Lowland SemiDesert and Desert Vegetation (Sebsebe, 1996; Zerihun, 2000).

Increasing the amount of trees can potentially slow the accumulation of atmospheric carbon (Brown, 2002).

Forest resources in Ethiopia have experienced so much pressure due to increasing need for wood products and conversion to agriculture. Hence, the trend in Ethiopia today is to protect the remaining natural forests for their various social, economic and environmental values. On the other hand, there is increasing demand for wood and wood products. To strike the balance between the two interests, afforestation/reforestation (here after referred to as plantations) is very important (FAO, 2001).

A number of authors and national or sub-national inventory projects, for instance ENEC-CESEN (1986), LUPRD-MOA, and the World Bank-funded Woody Biomass Inventory and Strategic Planning Project (WBISPP) have conducted assessments and documented the extent of forest resources and other land uses of Ethiopia. Among these, WBISPP is a key source of information on forests and other land uses in Ethiopia. According to WPISPP (2005), the land cover types in Ethiopia are classified into nine major types. However, in the recent forest proclamation (No. 542/2007), high forests, woodlands and bamboo forests are recognized as forests. Based on WBISPP report on the land use/land cover statistics in Ethiopia, woody Vegetations including high forests cover over $50 \%$ of the land (WBISPP, 2005). The definition of forest is ambiguous in the IPCC Good practices Guideline. However, according to the definition of FAO (2001), the vegetations of Ethiopia that may be considered as 'forests' are natural high forests, woodlands, plantations and bamboo forests, accounted an estimated area of 35.13 million ha. But, if the shrub lands are included to this (considering the IPCC definition of forests), the estimated cover becomes over 50\% (61.62 million ha). The nine vegetation types distinguished in Ethiopia are: Afro-alpine and Sub-Afro-alpine, Dry Evergreen Montane Forest, Moist Evergreen Montane Forest, Acacia-Commiphora (Small Leaved) Woodland, Combretum-Terminalia (Broad Leaved) Woodland, Lowland Dry Forests, Wetland (swamps, lakes, rivers and riparian) Vegetation, Evergreen Scrub Vegetation, and Lowland Semi-Desert and Desert Vegetation (Zerihun Woldu, 2000).

The practice of forests management and conservation in all areas throughout the country has been becoming a big challenge since most of the activities were not community based (Dessalegn Rahmato, 2001). In addition to this population growth at alarming rate increases the demand towards forest products and this in turn puts a 
pressure on the natural forest to be degraded and facilitate the erosion process (Alemayehu Wassie and Demel Teketay, 2006).

As this study is the first and the only study conducted on this forest it focused on primarily investigating the status, composition and species diversity of the study area to protect the deforestation activities by the local communities and to enhance the conservation and management of the forest ecosystem.

\section{Objective}

The overall objective of this study was focused on the current status and the floral diversity of Sekelemariyam Stat forest for the conservation and management of the forest resource and rehabilitation of the surrounding area.

\section{Materials and Methods}

\subsection{Geographical Location}

This study was conducted in Dembecha district, Amhara National Regional State, north western parts of Ethiopia which is situated within $37^{\circ} 27^{\prime}$ and $37^{\circ} 30^{\prime}$ east, and $10^{\circ} 34^{\prime}$ and $10^{\circ} 36^{\prime}$ north, near Dembecha Town in west Gojam Zone. The study covers 543 hectares. The forest has an altitudinal gradient ranging from $2249 \mathrm{~m}$ to $2470 \mathrm{~m}$ above sea level. This forest contains diverse fauna and flora species which are currently found in danger.

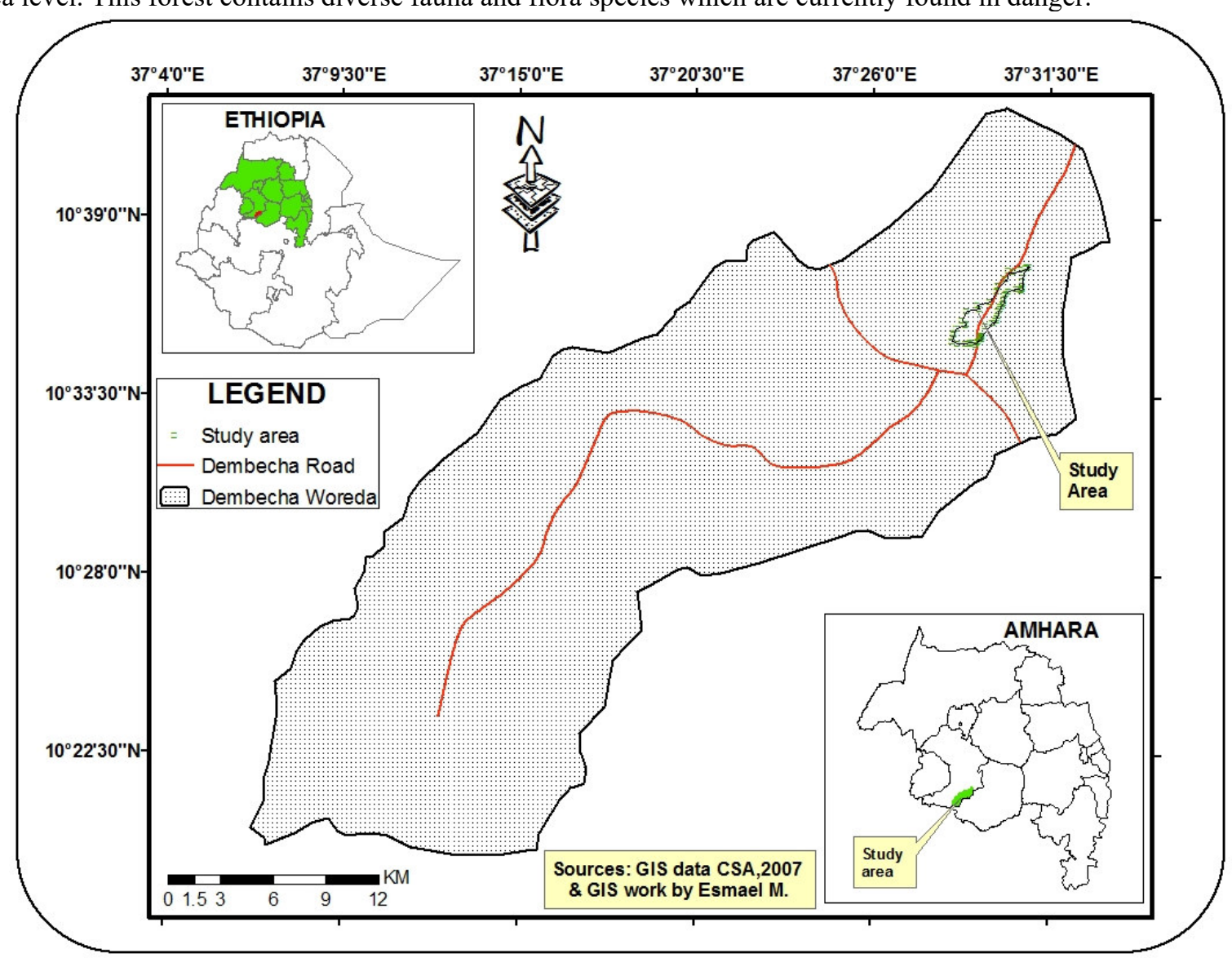

Figure 1: Map of Ethiopia showing Regional States and the Study Area

\subsection{Topography and climate}

The topography of the Forest is characterized by dissected plateaus bordered by cultivated lands in all directions. The natural forest vegetation is concentrated at the middle and lowest altitudes, while the upper altitude which is the top plateau area of the forest is mainly occupied by plantations. Plantations are also scattered in some flat areas of the middle altitudes. It is characterized by steeply sloped areas with huge Rocky Mountains extended throughout the middle parts of the forest. The forest also consists of small and seasonal rivers drained from the top of the forest to the lower settlement areas.

The mean annual rainfall of the study area is $1502.01 \mathrm{~mm}$ ranging from $1283.10 \mathrm{~mm}$ minimum in 2009 to maximum of $1639.4 \mathrm{~mm}$ in 2010 with the rains mainly falling from the end of May to September. The mean temperature of the surrounding area is about $18.74{ }^{\circ} \mathrm{C}$ with a maximum of $27.04{ }^{\circ} \mathrm{C}$ and minimum of $9.65^{\circ} \mathrm{C}$ which was recorded from 2005 to 2010 G.C. 


\subsection{Sampling Techniques}

The transect approach was more appropriate and applied for vegetation sampling. Therefore, it was done deliberately across areas where there are marked environmental gradients according to Kent and Coker (1992). Sampling sites from the forest were arranged by the line transects from the bottom area of the forest to top directions covering the whole range of altitudes.

\subsubsection{Sample plots}

Forest community data was collected from permanent plots in $10 \mathrm{~m} \times 20 \mathrm{~m}$ along with the transect lines. A vegetation census was used to collect data on forest structure and species composition. All trees in these plots having $\mathrm{DBH}>5 \mathrm{~cm}$ were recorded in all 66 sample plots.

\subsection{Methods of Data Analysis}

Different DBH classes were constructed, and the density distribution of tree and shrub species was computed in each class (McCune and Mefford, 1999; Magurran, 1988). Structural analysis was performed on the basis of density, frequency, DBH and basal area per hectare. The distribution of the size classes were evaluated by computing the density of individuals with $\mathrm{DBH}>10 \mathrm{~cm}$ and $>20 \mathrm{~cm}$ as well as the ratio of the former to the latter. According to Grubb et al. (1963), the ratio of 'density at DBH class $>10 \mathrm{~cm}$ to density at DBH class $>20 \mathrm{~cm}$ can be used as a measure of the distribution of the different size classes. The patterns of species population structure detected were interpreted as a sign for the alteration in population dynamics in the forests (Popma et al., 1988). The following structural parameters were calculated for some species following Mueller- Dombois and Ellenberg (1974) and Martin (1995) as follows:

Percent frequency of a species $=$ the number of plots in which that species occurs/total number of plots X 100 Relative frequency $=$ Frequency of species/total frequency of all species X 100

Density of a species $=$ the number of individuals of that species/area sampled

Relative density $=$ Density of species A/total density of all species X 100

Basal area $(\mathrm{m} 2)=(\mathrm{DBH} / 2) 2 \mathrm{p}$ or $\mathrm{DBH}^{2} * 0.785$ where $\mathrm{DBH}$ is the Diameter at

Breast Height $(\mathrm{cm}), \mathrm{p}=3.14$

Dominance $=$ Total of basal area $/$ area sampled

Relative dominance $=$ Dominance of species A/total dominance of all species X 100

Importance Value Index = Relative density + Relative frequency + Relative dominance

Diversity Analysis

Species Richness

Species richness is a measure of the number of species found in a sample. Since the larger the sample, the more species we would expect to find, the number of species is divided by the square root of the number of individuals in the sample. This particular measure of species richness is known as D, the Menhinick's index.

$$
\mathbf{D}=\underline{\mathbf{s}}
$$

Where,

$\mathrm{S}=$ equals the number of different species represented in your sample, and

$\mathrm{N}=$ equals the total number of individual organisms in your sample.

\section{Species Diversity}

The diversity of tree species was determined using the Shannon-Wiener diversity index $(\mathrm{H})$ and evenness or equitability index (E) (Barnes et al., 1998; Krebs, 1989). As a measure of species diversity. It was calculate to be 2.783 using the Shannon index, H shown below.

A diversity index, taking into accounts the number of individuals as well as number of species. Varies from zero (0) for communities with only a single species to one (1) for communities with many species, each with few individuals. Shannon's index is most suitable for plant, bird and mammal studies

\section{Shannon Diversity Index}

$$
H=\sum_{i=1}^{S}-\left(P_{i} * \ln P_{i}\right)
$$

where:

$\mathrm{H}=$ the Shannon diversity index

$\mathrm{P}_{\mathrm{i}}=$ fraction of the entire population made up of species $\mathrm{i}$

$\mathrm{S}=$ numbers of species encountered

$\sum=$ sum from species 1 to species $\mathrm{S}$

Note: The power to which the base e $(\mathrm{e}=2.718281828 \ldots \ldots)$ must be raised to obtain a number is called the natural logarithm $(\ln )$ of the number. 


\section{RESULTS AND DISCUSSION}

\subsection{Floristic Composition of the Forest}

Thus, in this study, thirty three tree species were recorded from the study site, Sekelemariam State Forest. Among this species, Croton macrostachys accounted the maximum number of $254(16.61 \%)$ of the total species followed by Cupressus lusitanica which accounted for $187(12.23 \%)$ of stem in the study site. Eucalyptus citriodora, E. globuls, Acacia abyssinica and Albizzia schimperiana were found to be dominantly next to the above mentioned two most dominant species, respectively. Species, such as, Acacia mearnsii, Calpurnia auria, Bersama abyssinica, Maesa lanceolata and Buddeleja polystachya were relatively dominant species whilst the rest of tree species have been found sparsely distributed in the study site. Out of the 33 species examined in the study Croton macrostachyus contributed the highest overall stem density with stand numbers 192.42 trees per ha. The two dominant species in stem density were Croton macrostachyus and Cupressus lusitanica with stem density 192.42 trees ha ${ }^{-1}$ and 141.67 trees ha-1, respectively.

\subsection{Field Measurements}

\section{$\circ \quad$ Vegetation Survey: Diameter and Height Measurement}

The DBH and height of all trees having diameter $\geq 5 \mathrm{~cm}$ in study site were measured as follows: Diameter (at 1.3 $\mathrm{m}$ above the ground unless there is abnormality) of all living trees (woody plants) were measured using diameter tape.

\section{DBH Size Class Distribution of Trees}

Diameter distribution of trees with DBH larger than $5 \mathrm{~cm}$ this plot is shown in table 1 . The frequency of trees in this DBH size class gradually decreases as DBH class decreases and this shows there is high density in small class, and has very little number of large trees in Sekelemariam State forest and this trend also shows J-shape. This outcome indicated that some limiting factors such as soil, topography play an important role on the tree growth. The largest number of trees in all 66 plots belonged to the DBH class 5-15 and 15-25 cm. Among all species examined in this study, only (2.94\%) of E. globulus and (18.18\%) of E. camaldulensis were found to possess a DBH class greater than $55 \mathrm{~cm}$. About $4.41 \%, 9.09 \%$ and $7.81 \%$ of E. globulus, E. camaldulensis and Acacia abyssinica have a DBH size class range between $45-55 \mathrm{~cm}$, respectively. These species constitute the larger plant species in the study site. Approximately more than $65 \%$ of these species have a DBH size greater than $25 \mathrm{~cm}$. Some species such as Calpurnia auriea, Clausena anisata, Rosa abyssinica, Olinia rochetiana and Protea gaguedi entirely possessed the lowest DBH class $(5-15 \mathrm{~cm})$. Plants species include Croton macrostachyus, Vernonia amygdalina, prunus africana, Maytenus senegalensis, Ficus sur, Erythrina brucei, Scheffleria abyssinica, Schrebera alata and Ritchia albersii have more than 50\% of their DBH size found between $15-25$ and $25-35 \mathrm{~cm}$. The average DBH and height value in this forest were $29.83 \mathrm{~cm}$ and $28.91 \mathrm{~m}$, respectively.

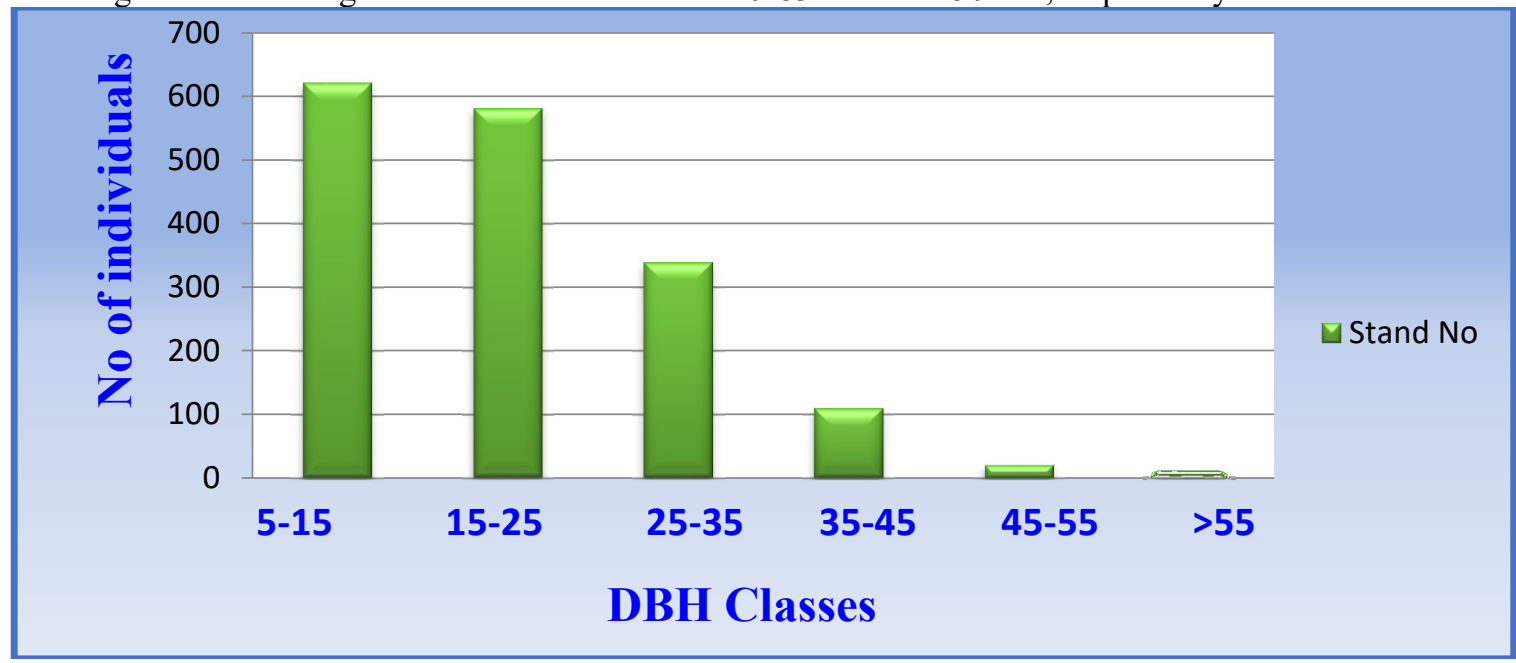

Figure 2: DBH Size Class Distribution of Trees

II. Height Size Class Distribution of Trees

A total of 1529 trees stands in different sizes in the sampling plots were recorded to analyze their height and DBH relationships. Eucalyptus tree species, E. globulus, E. camaldulensis and E. citriodora are seen to have dominated in height. Cupressus lusitanica also covered the maximum height class range between $31-40 \mathrm{~m}$. The height of majority tree species in the study site is found between $21-30 \mathrm{~m}$ followed by $11-20 \mathrm{~m}$ height classes, the medium height classes. E. globulus, E. citriodora, E. camaldulensis, Acacia abyssinica, Croton macrostachys, Albizzia schimperiana, Cupressus lusitanica, Acacia mearnsii, Veronia amygdalina, Bersama abyssinica, Calpurnia auria, Buddeleja polystachya, Carissa spinarum, Clausena anisata, Prunus africana Maytenus senegalensis and Maytenus ovatus mainly have heights between 21-30 m. 
Generally, the maximum height class of the study site was entirely covered by plantations whereas slightly medium and almost all lowest height classes of trees were occupied by natural plants. This indicates that the huge natural plants might be destroyed and replaced by plantations through reforestation.

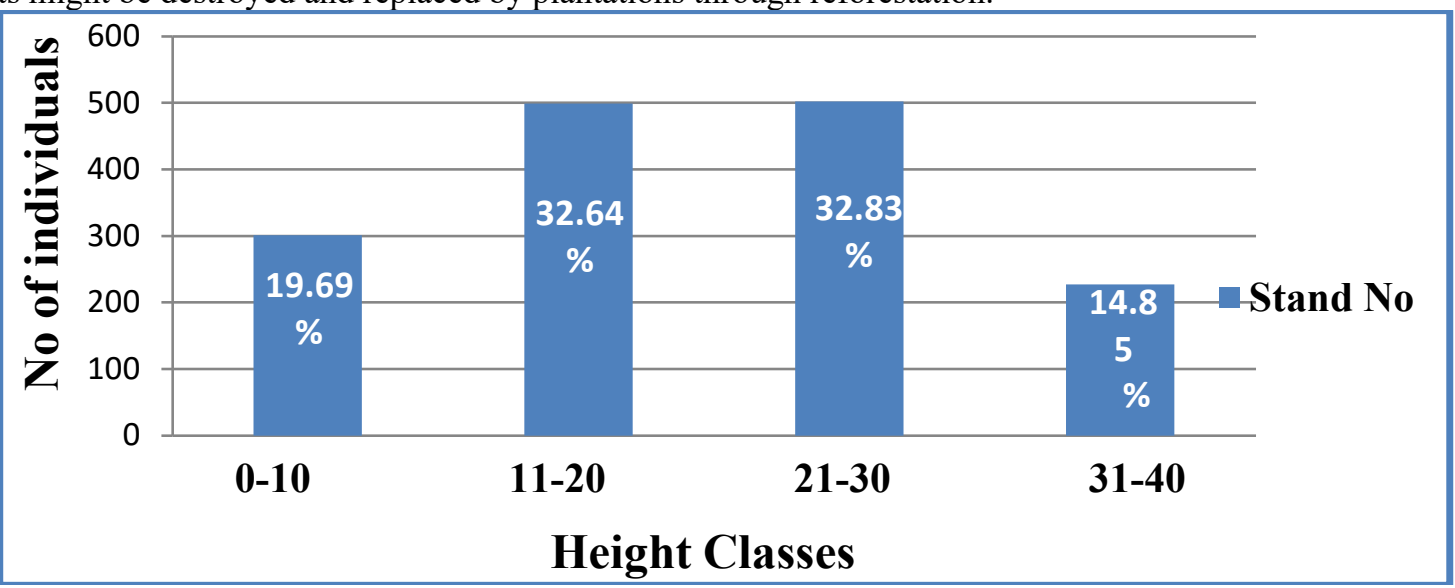

Figure1: Height Size Class Distribution of Trees

\section{Density}

The overall density of tree species of Sekelemariyam State Forest DBH $>5 \mathrm{~cm}$ was computed to be $\mathbf{1 1 5 8}$ stems ha-

\section{Frequency}

The frequency of each tree species is calculated by dividing the number of quadrat at which that species occurred (in at least one quadrant) by the total number of quadrat. It gives an approximate indication for homogeneity and heterogeneity of vegetation. Lamprecht (1989) pointed out that high value in high frequency and lower value in the lower frequency classes indicate vegetation homogeneity. Conversely, high percentage of number of species in the lower frequency class and low percentage of number of species in the higher frequency classes indicates high degree of floristic heterogeneity (Simson==--- Shibru and Girma Balcha, 2004).

As it is shown in table 1, Croton macrostachyus occurred most frequently at $53.03 \%$ of frequency found in 35 plots out of 66 followed by Acacia abyssinica (46.97\%, in 31 plots), Cupressus lusitanica (36.36\% in 24 plots), Albizzia schimperiana (25.76\%, in 17 plots), E. globulus $(22.73 \%$, in 15 plots and Terminalia schimperiana $(16.67 \%$, in 11 plots), respectively.

\section{Important Value Index (IVI)}

The importance value provides an overall estimate of the influence or importance of the tree species in the local community of organisms. The importance value will be of greatest interest in future analyses of the tree survey data because it provides a way to plot over time the influence of a particular tree species on the local community. Curtis and McIntosh (1951) pointed out that IVI gives a more realistic figure of dominance from structural point of view.

Therefore, in terms of their IVI values, Croton macrostachyus, Eucalyptus citriodora, Cupressus lusitanica, Acacia abyssinica, Eucalyptus globuls and Albizia schimperiana have larger IVI values, respectively which implies as they are highly dominant and ecologically most significant tree species in the study forest. The leading dominant and ecologically most significant species might also be the most successful species in regeneration, pathogen resistance, grow in shade, and in completion with other species, least preferred by animals, attractions of pollinators and seed predators that facilitate seed dispersal within the existing environmental conditions of the study area (Table 2).

Table 1: Mean H, Mean DBH and percent of Frequency of the study forest.

\begin{tabular}{|c|l|c|c|c|c|}
\hline No & Scientific Name & $\begin{array}{c}\text { Mean } \\
\text { H }\end{array}$ & $\begin{array}{l}\text { Mean } \\
\text { DBH }\end{array}$ & $\begin{array}{c}\text { No. of plots } \\
\text { that } \\
\text { species found }\end{array}$ & $\begin{array}{c}\text { Percent } \\
\text { of } \\
\text { frequency }\end{array}$ \\
\hline 1 & Eucalyptus globulus & 28.91 & 29.83 & 15 & 22.73 \\
\hline 2 & Eucalyptus citriodora & 28.66 & 24.01 & 7 & 10.61 \\
\hline 3 & Eucalyptus camaldulensis & 32.36 & 39.10 & 5 & 7.58 \\
\hline 4 & Acacia abyssinica & 18.63 & 26.04 & 31 & 46.97 \\
\hline 5 & Croton macrostachys & 18.21 & 18.22 & 36 & 53.03 \\
\hline 6 & Albizzia schimperiana & 17.28 & 16.01 & 17 & 25.76 \\
\hline 7 & Cupressus lusitanica Mil & 27.67 & 21.61 & 36 & 36.36 \\
\hline 8 & Acacia mearnsii De Willd & 21.32 & 22.29 & 6 & 7.58 \\
\hline 9 & Acacia amygdalina & 11.83 & 18.24 & 9 & 13.64 \\
\hline
\end{tabular}




\begin{tabular}{|l|l|c|c|c|c|}
\hline No & Scientific Name & $\begin{array}{c}\text { Mean } \\
\text { H }\end{array}$ & $\begin{array}{c}\text { Mean } \\
\text { DBH }\end{array}$ & $\begin{array}{c}\text { No. of plots } \\
\text { that } \\
\text { species found }\end{array}$ & $\begin{array}{c}\text { Percent } \\
\text { of } \\
\text { frequency }\end{array}$ \\
\hline 10 & Bersama abyssinica & 11.47 & 11.33 & 15 & 9.09 \\
\hline 11 & Alpurnia auria (Ait.) Benth & 7.02 & 7.21 & 7 & 10.61 \\
\hline 12 & Buddeleja polystachya & 9.98 & 13.65 & 10 & 15.15 \\
\hline 13 & Buddeleja polystachya & 12.63 & 13.65 & 3 & 4.55 \\
\hline 14 & Carissa edulis & 7.00 & 5.90 & 2 & 3.03 \\
\hline 15 & Clausena anisata & 5.50 & 6.92 & 7 & 10.61 \\
\hline 16 & Prunus africana (Hochst.ex A.Rich.) Harms & 21.50 & 25.59 & 2 & 3.03 \\
\hline 17 & Maytenus senegalensis (Lam.) Exell & 13.88 & 17.98 & 6 & 9.09 \\
\hline 18 & Maytenus ovatus & 5.33 & 9.45 & 1 & 1.52 \\
\hline 19 & Rosa abyssinica & 19.50 & 6.69 & 2 & 3.03 \\
\hline 20 & Maytenus arbutifolia & 9.50 & 8.52 & 2 & 3.03 \\
\hline 21 & Measa lanceolata & 9.14 & 9.71 & 12 & 16.67 \\
\hline 22 & Terminalia schimperiana & 8.00 & 5.73 & 1 & 1.52 \\
\hline 23 & Allopylus abyssinicus (Hochst.) Redlk. & 13.70 & 15.99 & 1 & 3.03 \\
\hline 24 & Ficus sur. & 18.67 & 16.46 & 6 & 3.03 \\
\hline 25 & Erythrina brucei & 20.67 & 32.91 & 1 & 1.52 \\
\hline 26 & Olinia usambarensis & 9.21 & 9.14 & 1 & 9.09 \\
\hline 27 & Prottea gaguedi & 3.00 & 6.37 & 1 & 1.52 \\
\hline 28 & Scheffleria abyssinica & 12.50 & 19.11 & 1 & 1.52 \\
\hline 29 & Dovialis abyssinica (A.Rich.)Warb & 7.00 & 11.15 & 2 & 1.52 \\
\hline 30 & Schrebera alata (Hochst.) Welw & 16.50 & 20.38 & 1 & 3.03 \\
\hline 31 & Richia albersii & 12.00 & 15.29 & 1 & 1.52 \\
\hline 32 & Rothmannia urcelliformis & 9.93 & 9.55 & 1 & 6.06 \\
\hline 33 & Flacourtia indica (Burmif.) Merr. & 10.17 & 24.52 & 1 & 2 \\
\hline
\end{tabular}

Based on the table above on (table 1), the species Croton macrostachys, Acacia abyssinicaand Cupressus lusitanica Mil constitute the highest percentage frequency $(53.03 \%, 46.97 \%$ and $36.36 \%$ ) respectively, while Maytenus ovatus, Terminalia schimperiana, Erythrina brucei. Prottea gaguedi, Scheffleria abyssinica and Richia albersii showed the lowest percentage frequency $(1.52 \%)$.

Table 2: Relative frequency, Relative density, Relative dominance and Importance value index of the dominant woody species of Sekelemariyam State Forest.

\begin{tabular}{|c|l|c|c|c|c|c|}
\hline No & Scientific Name & $\begin{array}{c}\text { Relative } \\
\text { density }\end{array}$ & $\begin{array}{c}\text { Spp density } \\
\text { ha }\end{array}$ & $\begin{array}{c}\text { Relative } \\
\text { frequency }\end{array}$ & $\begin{array}{c}\text { Relative } \\
\text { dominance }\end{array}$ & IVI \\
\hline 1 & Eucalyptus globulus & 8.895 & 103.03 & 6.53 & $\mathbf{1 0 . 4 0}$ & $\mathbf{2 5 . 8 2}$ \\
\hline 2 & Eucalyptus citriodora & 9.026 & 104.55 & 3.05 & $\mathbf{2 2 . 2 8}$ & $\mathbf{3 4 . 3 6}$ \\
\hline 3 & Eucalyptus camaldulensis & 1.439 & 16.67 & 2.18 & $\mathbf{8 . 8 7}$ & $\mathbf{1 2 . 4 9}$ \\
\hline 4 & Acacia abyssinica & 8.371 & 96.97 & 13.50 & $\mathbf{5 . 0 3}$ & $\mathbf{2 6 . 9 0}$ \\
\hline 5 & Croton macrostachys & 16.612 & 192.42 & 15.24 & $\mathbf{3 . 0 9}$ & $\mathbf{3 4 . 9 4}$ \\
\hline 6 & Albizzia schimperiana & 12.034 & 139.39 & 7.40 & $\mathbf{3 . 1 2}$ & $\mathbf{2 2 . 5 5}$ \\
\hline 7 & Cupressus lusitanica & 12.230 & 141.67 & 10.45 & $\mathbf{4 . 1 7}$ & $\mathbf{2 6 . 8 5}$ \\
\hline 8 & Acacia mearnsii De Willd & 3.859 & 44.70 & 2.18 & $\mathbf{5 . 7 8}$ & $\mathbf{1 1 . 8 2}$ \\
\hline 9 & Acacia amygdalina & 1.962 & 22.73 & 3.92 & $\mathbf{1 . 4 6}$ & $\mathbf{7 . 3 4}$ \\
\hline 10 & Bersama abyssinica & 3.074 & 35.61 & 2.61 & $\mathbf{0 . 5 3}$ & $\mathbf{6 . 2 1}$ \\
\hline 11 & Alpurnia auria (Ait.) Benth & 3.270 & 37.88 & 3.05 & $\mathbf{0 . 4 3}$ & $\mathbf{6 . 7 5}$ \\
\hline 12 & Buddeleja polystachya & 2.747 & 31.82 & 4.35 & $\mathbf{1 . 0 1}$ & $\mathbf{8 . 1 0}$ \\
\hline 13 & Buddeleja polystachya & 2.616 & 30.30 & 1.31 & $\mathbf{3 . 2 7}$ & $\mathbf{7 . 2 0}$ \\
\hline 14 & Carissa edulis & 0.262 & 3.03 & 0.87 & $\mathbf{0 . 0 9}$ & $\mathbf{1 . 2 2}$ \\
\hline 15 & Clausena anisata & 1.962 & 22.73 & 3.05 & $\mathbf{0 . 2 7}$ & $\mathbf{5 . 2 8}$ \\
\hline 16 & Prunus africana (Hochst.ex A.Rich.) & & & & & \\
& Harms & 0.785 & 9.09 & 0.87 & $\mathbf{5 . 1 8}$ & $\mathbf{6 . 8 3}$ \\
\hline 17 & Maytenus senegalensis (Lam.) Exell & 1.700 & 19.70 & 2.61 & $\mathbf{1 . 4 2}$ & $\mathbf{5 . 7 3}$ \\
\hline 18 & Maytenus ovatus & 0.392 & 4.55 & 0.44 & $\mathbf{0 . 7 1}$ & $\mathbf{1 . 5 4}$ \\
\hline 19 & Rosa abyssinica & 0.523 & 6.06 & 0.87 & $\mathbf{0 . 2 4}$ & $\mathbf{1 . 6 3}$ \\
\hline 20 & Maytenus arbutifolia & 0.262 & 3.03 & 0.87 & $\mathbf{0 . 1 9}$ & $\mathbf{1 . 3 2}$ \\
\hline 21 & Measa lanceolata & 2.878 & 33.33 & 4.79 & $\mathbf{0 . 3 9}$ & $\mathbf{8 . 0 6}$ \\
\hline
\end{tabular}




\begin{tabular}{|c|l|c|c|c|c|c|}
\hline No & Scientific Name & $\begin{array}{c}\text { Relative } \\
\text { density }\end{array}$ & $\begin{array}{c}\text { Spp density } \\
\text { /ha }\end{array}$ & $\begin{array}{c}\text { Relative } \\
\text { frequency } \\
0.131\end{array}$ & $\begin{array}{c}\text { Relative } \\
\text { dominance } \\
\mathbf{0 . 0 9}\end{array}$ & IVI \\
\cline { 1 - 2 } 22 & Terminalia schimperiana & 0.66 \\
\hline 23 & Allopylus abyssinicus (Hochst.) Redlk. & 0.654 & 7.58 & 0.87 & $\mathbf{3 . 3 7}$ & $\mathbf{4 . 8 9}$ \\
\hline 24 & Ficus sur. & 0.392 & 4.55 & 0.87 & $\mathbf{0 . 7 1}$ & $\mathbf{1 . 9 8}$ \\
\hline 25 & Erythrina brucei & 0.785 & 9.09 & 0.44 & $\mathbf{5 . 7 1}$ & $\mathbf{6 . 9 4}$ \\
\hline 26 & Olinia usambarensis & 0.916 & 10.61 & 2.61 & $\mathbf{1 . 5 4}$ & $\mathbf{5 . 0 7}$ \\
\hline 27 & Prottea gaguedi & 0.131 & 1.52 & 0.44 & $\mathbf{0 . 1 1}$ & $\mathbf{0 . 6 8}$ \\
\hline 28 & Scheffleria abyssinica & 0.131 & 0.131 & 0.44 & $\mathbf{0 . 9 6}$ & $\mathbf{1 . 5 3}$ \\
\hline 29 & Dovialis abyssinica (A.Rich.)Warb & 0.262 & 0.262 & 0.44 & $\mathbf{0 . 3 3}$ & $\mathbf{1 . 0 3}$ \\
\hline 30 & Schrebera alata (Hochst.) Welw & 0.262 & 0.262 & 0.87 & $\mathbf{2 . 1 9}$ & $\mathbf{3 . 3 2}$ \\
\hline 31 & Richia albersii & 0.131 & 0.131 & 0.44 & $\mathbf{0 . 6 2}$ & $\mathbf{1 . 1 9}$ \\
\hline 32 & Rothmannia urcelliformis & 0.916 & 0.916 & 1.74 & $\mathbf{1 . 6 8}$ & $\mathbf{4 . 3 4}$ \\
\hline 33 & Flacourtia indica (Burmif.) Merr. & 0.392 & 0.392 & 0.44 & $\mathbf{4 . 7 5}$ & $\mathbf{5 . 5 9}$ \\
\hline
\end{tabular}

Table 3: DBH class distribution of each tree species in percentage

\begin{tabular}{|c|c|c|c|c|c|c|c|c|c|c|c|c|}
\hline \multirow[b]{3}{*}{ Tree code } & \multicolumn{12}{|c|}{ DBH Classes } \\
\hline & \multicolumn{2}{|c|}{$5-15$} & \multicolumn{2}{|c|}{$15-25$} & \multicolumn{2}{|c|}{$25-35$} & \multicolumn{2}{|c|}{$35-45$} & \multicolumn{2}{|c|}{$45-55$} & \multicolumn{2}{|l|}{$>55$} \\
\hline & No & $\%$ & No & $\%$ & No & $\%$ & No & $\%$ & No & $\%$ & No & $\%$ \\
\hline 1 & 12 & 10.29 & 28 & 22.06 & 44 & 31.82 & 36 & 27.94 & 6 & 4.41 & 4 & 2.94 \\
\hline 2 & 22 & 17.39 & 43 & 33.33 & 62 & 47.83 & 1 & 2.90 & 0 & 0.00 & 0 & 0.00 \\
\hline 3 & 2 & 9.09 & 0 & 0.00 & 10 & 45.45 & 4 & 18.18 & 2 & 9.09 & 4 & 18.18 \\
\hline 4 & 18 & 14.06 & 50 & 39.06 & 26 & 20.31 & 22 & 17.19 & 10 & 7.81 & 0 & 0.00 \\
\hline 5 & 101 & 43.70 & 91 & 36.61 & 36 & 14.17 & 9 & 3.54 & 0 & 0.00 & 3 & 1.18 \\
\hline 6 & 100 & 54.35 & 52 & 28.26 & 28 & 15.22 & 4 & 2.17 & 0 & 0.00 & 0 & 0.00 \\
\hline 7 & 44 & 23.53 & 84 & 14.44 & 94 & 50.27 & 22 & 11.76 & 0 & 0.00 & 0 & 0.00 \\
\hline 8 & 8 & 13.56 & 31 & 54.24 & 15 & 30.51 & 0 & 0.00 & 0 & 0.00 & 0 & 0.00 \\
\hline 9 & 10 & 33.33 & 14 & 46.67 & 4 & 13.33 & 2 & 6.67 & 0 & 0.00 & 0 & 0.00 \\
\hline 10 & 40 & 85.11 & 7 & 14.89 & 0 & 0.00 & 0 & 0.00 & 0 & 0.00 & 0 & 0.00 \\
\hline 11 & 44 & 100 & 0 & 0.00 & 0 & 0.00 & 0 & 0.00 & 0 & 0.00 & 0 & 0.00 \\
\hline 12 & 26 & 61.90 & 15 & 35.71 & 0 & 0.00 & 0 & 0.00 & 0 & 0.00 & 0 & 0.00 \\
\hline 13 & 30 & 75.00 & 8 & 20.00 & 0 & 0.00 & 2 & 5.00 & 0 & 0.00 & 0 & 0.00 \\
\hline 14 & 4 & 100 & 0 & 0.00 & 0 & 0.00 & 0 & 0.00 & 0 & 0.00 & 0 & 0.00 \\
\hline 15 & 30 & 100 & 0 & 0.00 & 0 & 0.00 & 0 & 0.00 & 0 & 0.00 & 0 & 0.00 \\
\hline 16 & 0 & 0.00 & 8 & 66.67 & 4 & 33.33 & 0 & 0.00 & 0 & 0.00 & 0 & 0.00 \\
\hline 17 & 6 & 23.08 & 8 & 61.54 & 4 & 15.38 & 0 & 0.00 & 0 & 0.00 & 0 & 0.00 \\
\hline 18 & 6 & 100 & 0 & 0.00 & 0 & 0.00 & 0 & 0.00 & 0 & 0.00 & 0 & 0.00 \\
\hline 19 & 8 & 100 & 0 & 0.00 & 0 & 0.00 & 0 & 0.00 & 0 & 0.00 & 0 & 0.00 \\
\hline 20 & 4 & 100 & 0 & 0.00 & 0 & 0.00 & 0 & 0.00 & 0 & 0.00 & 0 & 0.00 \\
\hline 21 & 36 & 81.82 & 6 & 13.64 & 2 & 4.55 & & 0.00 & 0 & 0.00 & 0 & 0.00 \\
\hline 22 & 2 & 100 & 0 & \begin{tabular}{|l|l|}
0.00 \\
\end{tabular} & 0 & 0.00 & 0 & \begin{tabular}{|l|l|}
0.00 \\
\end{tabular} & 0 & 0.00 & 0 & 0.00 \\
\hline 23 & 6 & 60.00 & 4 & 40.00 & 0 & 0.00 & 0 & 0.00 & 0 & 0.00 & 0 & 0.00 \\
\hline 24 & 6 & 50 & 6 & 50 & 0 & 0.00 & 0 & 0.00 & 0 & 0.00 & 0 & 0.00 \\
\hline 25 & 0 & 0.00 & 4 & 100 & 0 & 0.00 & 0 & \begin{tabular}{|l|l|}
0.00 \\
\end{tabular} & 0 & 0.00 & 0 & 0.00 \\
\hline 26 & 14 & 100 & 0 & 0.00 & 0 & 0.00 & 0 & 0.00 & 0 & 0.00 & 0 & 0.00 \\
\hline 27 & 2 & 100 & 0 & \begin{tabular}{|l|l|} 
\\
\end{tabular} & 0 & 0.00 & 0 & \begin{tabular}{|l|l|} 
\\
\end{tabular} & 0 & 0.00 & 0 & 0.00 \\
\hline 28 & 0 & 0.00 & 2 & 100 & 0 & 0.00 & 0 & \begin{tabular}{|l|l|}
0.00 \\
\end{tabular} & 0 & 0.00 & 0 & 0.00 \\
\hline 29 & 4 & 100 & 0 & 0.00 & 0 & 0.00 & 0 & 0.00 & 0 & 0.00 & 0 & 0.00 \\
\hline 30 & 2 & 50.0 & 2 & 50.00 & 0 & 0.00 & 0 & \begin{tabular}{|l|l|} 
\\
\end{tabular} & 0 & 0.00 & 0 & 0.00 \\
\hline 31 & 0 & 0.00 & 2 & 100 & 0 & 0.00 & 0 & 0.00 & 0 & 0.00 & 0 & 0.00 \\
\hline 32 & 12 & 85.71 & 2 & 14.29 & 0 & 0.00 & 0 & 0.00 & 0 & 0.00 & 0 & 0.00 \\
\hline 33 & 2 & 33.33 & 2 & 33.33 & 0 & 0.00 & 0 & \begin{tabular}{|l|l|} 
\\
\end{tabular} & 2 & 33.33 & 0 & 0.00 \\
\hline
\end{tabular}

\section{Conclusion}

\subsection{Forest Structure and Species Composition}

The forest is characterized by possessing different types of topographic (environmental)

Variables, such as slope, altitude and aspect gradients. Population structure is the distribution of individuals 
of each species in an arbitrarily diameter-height size classes to provide the overall regeneration profile of the study species (peters, 1996; Shiferaw Belachew, 2010).

Thus, in this study, thirty three tree species were recorded. Among this species, Croton macrostachys accounted the maximum number of $254(16.61 \%)$ of the total species followed by Cupressus lusitanica which accounted for $187(12.23 \%)$ of stem in the study site. Eucalyptus tree species, E. globulus, E. camaldulensis and E. citriodora are seen to have dominated in height. The height of majority tree species in the study site is found between 21-30 m.

Approximately more than $65 \%$ of these species have a DBH size greater than $25 \mathrm{~cm}$. species such as Calpurnia auriea, Clausena anisata, Rosa abyssinica Olinia rochetiana and protea gaguedi entirely possess the lowest DBH class $(5-15 \mathrm{~cm})$. The average DBH and height value in this forest were $29.83 \mathrm{~cm}$ and $28.91 \mathrm{~m}$, respectively.

\section{References}

Alemayehu Wassie and Demel Teketay (2006). Soil seed banks in Church forest of Northen Ethiopia:Implication for conservation of woody plants. Flora 201:32-43.

Barnes, B.V., Zak, D.R., Denton, S.R., Spurr, S.H. 1998. Forest Ecology, fourth ed. Wiley, New York.

Brown, S. 2002. Measuring carbon in forests: current status and future challenges. Environmental Pollution, 116(3): 363-372.

Curtis, J.T., and Macintosh, R.P. 1951. An upland forest continuum in the prairie forest border region of Wisconsin Ecology 32:476-96.

Dessalegn Rahmato (2001). Environmental change and state policy in Ethioipa:lessons from past experience. Forum for social studies, Addis Ababa.

ENEC/CESEN. 1986. Main Report (plus 13 technical reports and 26 supplementary reports)

FAO. 2001. The State of the World's Forests 2001, FAO Rome.

Kent, M. and Coker, P. 1992. Vegetation Description and Analysis. A practical approach olhaven Printing Press, London, Pp. 363

Krebs, C.J. 1989. Ecological Methodology. Harper Collins, New York.

Lamprecht, H. (1989). Silverculture in Tropics. Tropical Forest Ecosystems and their Tree Species-Possibilities and Methods of their Long-term Utilization. T2-Velagsgesells chaft $\mathrm{GmbH}$, RoBdort, Germany reports).

LUPRDĞMOA. 1985. Assistance to land use planning project. Phase I, Addis Ababa

Mesfin Sahle. 2011. Estimating and Mapping of Carbon Stocks based on Remote Sensing, GIS and Ground Survey in the Menagesha Suba State Forest, Ethiopia.

McCune, B. and Mefford, M.J., 1999. Multivariate Analysis of Ecological Data, Version 4.20.

Popma, J., Bongers, F. and Meave del Castillo, J., 1988. Patterns in the vertical structure of tropical lowland rain forest of Los Tuxtals, Mexico. Vegetatio 74:81-91.

Sebesibe Demissew (1988). The floristic composition of the Menagesha State Forest and the need to conserve such forests in Ethiopia. Mountain Research and Development 8: 243-24.

WBISPP. 2005. A national strategy plans for the biomass sector. Addis Ababa, Eth.

Zerihun Woldu. 2000. Forests in the vegetation types of Ethiopia and their status in the geographical context, pp. 1 \pm 48 . In: Sue Edwards, Abebe Demissie, Taye Bekele \& Gunther Haase (eds) Forest genetic resources conservation: principles, strategies and actions. Proceedings of the National Forest Genetic Resources Conservation Strategy Development Workshop, June 21Ğ22, 1999. Addis Ababa, Ethiopia. 